\title{
Research on Development of Rural Cooperative Organization
}

\author{
Li Liu \\ School of Marxism, Jilin Agricultural University, Changchun, Jilin 130018, China \\ Liuliu99666@126.com
}

\begin{abstract}
Though the background research of rural cooperative organization development, the paper points out the necessity of its generation and introduces several types existing in current rural cooperative organizations and finally, it proposes a list of points needed to be notice specially to better develop rural cooperative organizations which provides references for the further development and researches.
\end{abstract}

Keywords: new rural construction; rural cooperative organization; peasant interest.

\section{Introduction}

Agriculture, rural areas and peasants are always great matters to influence the overall development of Chinese economy and society. Experience of agricultural economy development from worldwide nations indicates that development of modern agricultural economy needs support from three aspects, they are property rights, technology and organizations. With the deepening of rural economic system reform and the propulsion of Chinese market economy system reform and based on the policy of household contract management, there exists scattered weak individual peasant and strong modern economic system with great scale. Facing with evolving competitive market, the scattered peasants have the disadvantages of small-scale, information access lack, low technology, low economic strength, over-scattered and low organizational degree, which causes the difficulty of agricultural products getting into market and increases the production cost of peasants and decreases the agricultural benefits and weaken the self-protection abilities of farmers and further causes the contradiction between scientization, commercialization and socialization of agriculture becoming more and more prominent. Such phenomenon has become the main matter to limit the further development of agricultural economy and increases of peasants' benefits [1].

Home and abroad practice shows that developing rural cooperative organization characterized by vulnerable groups' cooperation to cope with the contradiction between scattered farmers and evolving great market is the most effective institutional arrangement. Through cooperative organizations, it can enhance the organizational degree of farmers so as to get into market with higher level and greater scale to achieve the integration of small production and great market as well as small groups and large scale and industrialization of agriculture and to improve the overall competitiveness of agriculture, which is the core to solve the problem of "agriculture, rural areas and farmers".

\section{Concepts of rural cooperative organization}

\subsection{The concept and types of rural cooperative organization}

Rural cooperative organization refers to several cooperation and joint organizations which is organized by farmers and serve directly for agriculture in the agricultural cooperative economic campaigns. In China, rural cooperative organizations has come through tortuous development and evolution and so far, China has not legal rules on the connotation and denotation of rural cooperative organization and customarily, it defines following three kinds of organizations as rural cooperative organizations[2]:

(1) Community cooperative economic organization

Rural community cooperative economic organization is formed after the reform of the original system of rural people's commune which is known as "collective management and farmers decentralized management combining the upper operating system”. It takes land collective ownership as the foundation, take the countryside, the village area as the scope, take double management system 
as a feature, take management of land and collective assets, as well as serving members as the main functions. Compared with the international community, the community cooperative economic organization has obvious characteristics of non-cooperative economic organization: The business scope is regional, community; not comply with the principle of voluntary and mutually beneficial; lack of mechanism of democratic management; with strong administrative; not to return the surplus.

(2) Rural supply and marketing cooperatives, credit cooperatives

The rural supply and marketing cooperative is the self-raised fund, the voluntary association, and the "private" economic organization organized by the cooperation of the members. Its main task is to represent and protect the interests of members, to provide farmers with prenatal, delivery, postpartum service. The operation process should reflect the three principles of "the mass organization, democratic management, and flexible operation".

(3) New farmer specialized cooperative organization

New farmer specialized cooperative organization are various economic organizations and social groups based on Household contract management system during the period of the reform of rural market since 1980s. According to the principle of voluntary, democratic, equality and mutual benefit it is to provide prenatal, production, post natal services for the professional production of its members, to seek and maintain the social and economic interests of its members. The specific forms of these organizations include of farmers' professional associations, trade associations, farmers' Specialized Cooperatives and various farmers' Specialized Cooperative Organizations.

\subsection{The features of rural cooperative organization}

Rural cooperative organizations have the following features [3]:

(1)Members are main farmers, the purpose is to serve for the members and the basic principle is voluntarily in take part in the organizations and free to withdrawal from the organization.

(2) Rural cooperative organization is private and in the role of "invisible", "visible" hand, farmers establish it on the voluntary base. The formation type includes farmers spontaneously initiate type, hotshots leading and technology development type and the base drive type and so on. It is not the promoting outcome of any administrative power, its main body are farmers and it's an organization of respecting farmers' democratic rights, democratic decision-making.

(3) The rural cooperative organization doesn't take the profit as the purpose and it emphasizes on economic benefit externally, but internally it is in accordance with the transaction volume or the rate of transaction volume between members and the rural cooperative organization to return. The joint labor and management process fully reflect the principle of voluntary, equality and democracy.

(4) The rural cooperative organization is a legal person responsible for external business activities for the whole members and takes the profit maximization as the goal.

(5)Rural cooperative organizations break the restrictions of rural areas. Not only a cooperative economic organization can absorb other regions of the farmers, different regions of the cooperative economic organizations, such as the farms of city. Prisons can also be joint cooperation, vertical and horizontal development, mutual benefit and win-win,not restricted by region and Industry.

(6)The rural cooperative organization is the intermediary between the farmers and the government,the farmers and the market.On the one hand, the farmers can reflect the demands and express their demands through the influence of cooperative economic organizations.On the other hand, the cooperative economic organization can also help farmers to improve their discourse power,and have an equal status and trade with other markets.

\section{Some important issues to promote the development of rural cooperative organizations in the new rural construction}

The rural cooperative organization in China has experienced a difficult process, which is from scratch, from distortion to regression, and from neglecting to put more attention. Although the interests of farmers have a lot of favorable factors, such as the awareness of farmers' interests, the improvement of the market development, government policy support, etc., are still at the stage of development. There are still many problems need to be carefully thought and resolved. 
(1) The modernization of rural cooperative organizations

The social and economic activities are always the starting point of the individual. To achieve the maximum of their own interests in the market economy is the goal of personal behavior. As the main body of the economic activity, the pursuit of their interests, the famers will inevitably be driven in the production process to seek and accept the modern production elements. Therefore, the modernization of the rural cooperative organization is the cultivation of modern farmers. That is, as the main body of the agricultural cooperative organization construction, the new farmers not only have higher scientific and cultural quality and moral quality, but also have the professional skills, market ideas, and are civilized and law-abiding. This is not only the basis of the development of modern agriculture, but also the urgent need to build a new socialist countryside. Therefore, we must overcome the small peasant economy ideas, strengthen the farmers' market ideas, and improve the scientific and cultural quality of farmers. That is to say, the development of modern agriculture needs a large number of farmers, have the modern vision and quality, to achieve and support. Land itself is not the main factor to make people poor, but the ability and quality of the people is the key to determine the rich and the poor. To transform the human resources into human capital, to transform into the fundamental driving force to the development of rural economy, the education and training of farmers is a top priority [4].

(2) The positioning of the government in the rural cooperative organization

The development of the rural cooperative organization is a kind of institutional change, which begins with the change of the informal institution of the farmers' interests. In recent years, the abolition of agricultural taxes and the implementation of agricultural subsidies and other policies, which the central government have taken in the new rural construction, have achieved remarkable results. But it also needs the government, especially local governments to provide more system arrangement to establish the long-term organization of rural development. The development of rural cooperative organizations is the key to the development of rural economy. In the development of rural cooperative organizations, the local government has a relatively special status, position, function and behavior. On the one hand, it is an important link in the national superstructure system and the national administrative system; on the other hand, it is a powerful driving force for regional economic development in China. Such a dual identity makes the local government plays an important role in the development of rural economy in China. Although the government's support is necessary to improve the organization of farmers, but at first we must clearly define the scope of the government and the market, and the government's support should be to respect the market law and not interfere with the normal operation of the organization of farmers. At the same time, the government's responsibility should be reflected in the increase of special financial investment, and strengthen the financial support to make efforts to expand farmers specialized cooperative economic organization pilot demonstration scope and so on.

(3) Guiding the market to play a supporting role, to broaden the channels of farmers' income, improve farmers' income

The agricultural cooperative economy, which born in the modern market economy system, is bound to adapt to operation rules of the modern market economy. The rural market economy is faced with many development bottlenecks, since the market information is ever-changing. The fund problem of agricultural cooperation is the biggest bottleneck that restricts the development of rural cooperative organizations. Therefore, by taking the policy incentives to encourage industrial and commercial capital, private capital and investment in the developed regions, to establish a diversified investment mechanism. And according to the actual situation of rural economic development, to carry out different levels of agricultural cooperation is one of the effective methods to solve this problem. Encouraging and guiding various types of industrial and commercial enterprises to participate in the development of rural cooperative organizations in various ways. On the one hand, it can broaden the sources of funds, to attract business capital to participate in the construction of the rural cooperative economy, and broaden the channels of increasing farmers' income; On the other hand, it can also meet to the needs of enterprise development, so that enterprises can be corresponding to the agricultural cooperative organizations and establish long-term, stable relations of contract and avoid the consequences of a one-time Boyi and scattered farmers. At the same time, it 
also increases the income of the farmers, and improves the quality of life of the peasants. This is not only the basic starting point and the core task of the new rural construction, but also the fundamental purpose of developing the rural economic cooperation. But in the long term, it is important to improve the farmers' ability to resist market risk and improve the competitiveness of the farmers in the market.

\section{Summary}

Under the background of new rural construction, China has already had a solid foundation of developing rural cooperative organization. The continuous awakening of the main consciousness of the farmers' interests, the continuous improvement of the market development, the government's key concern and policy support also brought new opportunities for the development of rural cooperative organizations. Only through the combination of external driving force and internal driving force, the formation of a consistent power mechanism can really promote the healthy development of rural cooperative organizations, and provide a strong organizational support for the continuous increase of farmers' income, and the continuous development of rural economy.

\section{Acknowledgements}

Humanities and Social Sciences project from Ministry of Education: Mechanism Innovation and operation mechanism cooperative economic organizations of Chinese farmers - in Jilin Province (12YJC790118); Social Science Fund Project of Jilin Province: Contemporary Value of Marx and Engels Thought on Cooperative Economy (Project No: 2015M7) series of results.

Liu Li, Associate Professor, School of Marxism, Jilin Agricultural University, he received his PhD in Jilin University, Master Instructor, research direction: Agricultural Economics and Management.

\section{References}

[1]. Xiaolin He, Guohang Wu. Chinese rural cooperative organization development analysis in the new rural construction. Rural Economy. (2009) No.2, p. 45-49.

[2]. (Chunlei Yang: Research on the development and Countermeasures of rural cooperative economic organization in China (Master, Northwest Agriculture and Forestry University, China 2005). p.13.)

[3]. (Jianghua Zhang: Development stereotype analysis of rural cooperative organization (Master, Nanjing Forestry University, China 2007). p.11.)

[4]. Zhiqiang Wang. The current rural cooperative organization problems. Theory Journal. (2005) No. 1, p. 62-64. 